\title{
Analisis pengaruh pertumbuhan ekonomi dan pengangguran terbuka terhadap jumlah penduduk miskin di Kabupaten Tebo
}

\author{
Zurlinda*; Purwaka Hari Prihanto; Jaya Kusuma Edy
}

\author{
Prodi Ekonomi Pembangunan, Fak. Ekonomi dan Bisnis, Universitas Jambi \\ E-mail korespondensi: zurlinda95@gmail.com
}

\begin{abstract}
The purpose of this study was to determine and analyze: (1) the development of economic growth, open unemployment, and the number of poor people in Tebo Regency 2002-2015. (2) the development of poverty depth index and poverty severity index in Tebo Regency 2002-2015 period. (3) the effect of economic growth and open unemployment on the number of poor people in Tebo District 2002-2015. The method used in this research is the descriptive analysis method. The results of this study are economic growth and open unemployment in Tebo Regency for the period 2002-2015, which increased respectively by an average of $5.89 \%$ and $25.45 \%$ per year, then for the number of poor people in Tebo Regency in the 2002 period -2015 decreased by 1.36 percent. The results of this study also indicate a negative influence from the variables of economic growth and open unemployment on the number of poor people in Tebo Regency.
\end{abstract}

Keywords : Economic growth, Open unemployment, The number of poor people

Abstrak

Tujuan penelitian ini adalah untuk mengetahui dan menganalisis: (1) perkembangan pertumbuhan ekonomi, pengangguran terbuka dan jumlah penduduk miskin di Kabupaten Tebo periode 2002-2015. (2) perkembangan indeks kedalaman kemiskinan dan indeks keparahan kemiskinan di Kabupaten Tebo periode 2002-2015. (3) pengaruh pertumbuhan ekonomi, dan pengangguran terbuka terhadap jumlah penduduk miskin di Kabupaten Tebo 2002-2015. Metode yang digunakan dalam penelitian ini adalah metode analisis deskriptif. Hasil penelitian ini adalah pertumbuhan ekonomi dan pengangguran terbuka di Kabupaten Tebo periode Tahun 2002-2015 mengalami peningkatan masing-masing dengan rata-rata 5,89\% dan $25,45 \%$ per tahun, kemudian untuk jumlah penduduk miskin di Kabupaten Tebo pada periode Tahun 2002-2015 mengalami penurunan sebesar 1,36 persen. Hasil penelitian ini juga menunjukkan adanya pengaruh negative dari variabel pertumbuhan ekonomi dan pengangguran terbuka terhadap jumlah penduduk miskin di Kabupaten Tebo.

Kata kunci: Pertumbuhan ekonomi, Pengangguran terbuka, Jumlah penduduk miskin

\section{PENDAHULUAN}

Pembangunan ekonomi daerah merupakan proses dimana pemerintah daerah dan seluruh komponen masyarakat mengelola berbagai sumber daya yang ada secara bersama-sama. Melalui proses pembangunan akan tercipta lapangan perkejaan baru dan selanjutannya merangsang perkembangan kegiatan ekonomi dalam daerah tersebut. Tolak ukur pembangunan daerah diantaranya dapat dilihat dari pertumbuhan ekonomi, struktur ekonomi dan ketimpangan pendapatan antar penduduk, antar daerah maupun antar sektor. Suatu perekonomian akan mengalami pertumbuhan apabila tingkat kegiatan ekonominya lebih tinggi dari apa yang dicapai sebelumnya. Dengan kata lain 
pertumbuhan ekonomi adalah suatu proses kenaikan output perkapita dalam jangka panjang.

Dalam proses pembangunan di bidang ekonomi, negara-negara berkembangan termasuk indonesia menghadapi dilema dalam melaksanakan pembangunan. Apakah akan memilih pertumbuhan ekonomi yang tinggi dengan konsekuensi pemerataan terabaikan atau mengutamakan pemerataan dengan tingkat pertumbuhan ekonomi yang rendah

Pada teoritikus ilmu ekonomi pembangunan telah menyempurnakan makna, hakikat dan konsep pertumbuhan ekonomi. Domestik Bruto (PDB) dan Produk Domestik Regional Bruto (PDRB) saja, akan tetapi juga dibobot dengan hal-hal yang bersifat immaterial seperti kepuasan, kenikmatan, kebahagiaan, keamanan dan ketentraman yang di rasakan oleh masyarakat luas (Arsyad, 1999).

Masalah kemiskinan merupakan salah satu persoalan mendasar yang menjadi pusat perhatian di negara manapun. Salah satu aspek penting untuk mendukung strategi penanggulangan kemiskinan adalah tersedianya data kemiskinan yang dapat dipercaya dapat menjadi instrumen tangguh bagi pengambil kebijakan dalam memfokuskan perhatian pada kondisi hidup orang miskin. Data kemiskinan yang baik dapat digunakan untuk mengevaluasi kebijakan pemerintah terhadap kemiskinan, membandingkan kemiskinan antar waktu dan daerah, serta menentukan target pendudukan miskin dengan tujuan untuk memperbaiki kondisi mereka.

Berdasarkan data Badan Pusat Statistik Provinsi Jambi tahun 2015 jumlah penduduk miskin terus meningkat yakni tercatat pada Maret 2015 angka penduduk miskin sebanyak 300.710 jiwa meningkat sebesar 8,86 persen atau bertambah sebesar 19,0 ribu orang dibandingkan dengan penduduk miskin pada September 2014 yang sebesar 281,750 jiwa atau sebesar 8.39 persen (Data BPS Provinsi Jambi tahun 2015). Sedangkan menurut badan pusat statistik Provinsi Jambi Kota Jambi jumlah penduduk miskinnya pada tahun 2015 meningkat dari tahun 2014 yaitu pada tahun 2014 jumlah penduduk miskin di Kota Jambi sebanyak 50,95 ribu jiwa dan pada tahun 2015 jumlah penduduk miskin meningkat dari tahun sebelumnya menjadi 55,510 jiwa.

Berdasarkan data Badan Pusat Statistik (BPS), tahun 2015 selama lima tahun terakhir jumlah penduduk miskin di Kabupaten Tebo berfluktuasi. Pada tahun 2011 jumlah penduduk miskin sebanyak 20,000 jiwa, pada tahun 2012 jumlah penduduk miskin di Kabupaten Tebo menurun menjadi sebnayak 19,900 jiwa pada tahun 2013 jumlah penduduk miskin meningkat menjadi 21,970 jiwa.pada tahun 2014 jumlah penduduk miskin meningkat kembali menjadi 22,480 jiwa. Pada tahun 2015 jumlah penduduk miskin di Kabupaten Tebo meningkat dari tahun sebelumnya menjadi sebanyak 23,570 jiwa.

Pendapatan perkapita adalah pendapatan masing-masing penduduk yang diperoleh dari pembagian PDRB dengan jumlah penduduk pertengahan tahun. Jadi pada umumnya perhitungan pendapatan regional didasarkan pada harga berlaku, inflasi belum dieleminir sehingga kenaikan pendapatan yang diterima oleh faktor-faktor produksi dari waktu ke waktu belum tentu kenaikan riil. Oleh sebab itu perhitungan pendapatan regional juga dihitung berdasarkan harga konstan guna melihat kenaikan riil dari kenaikan nilai produksi suatu daerah. Mankiw (2000). Dengan adanya pertumbuhan ekonomi berarti terdapat peningkatan produksi sehingga menambah lapangan pekerjaan yang pada akhirnya akan mengurangi kemiskinan.

Berdasarkan data Badan Pusat Statistik (BPS) tahun 2015 perkembangan pertumbuhan ekonomi di Kabupaten Tebo lima tahun terakhir mengalami fluktuasi. Pada tahun 2011 pertumbuhan ekonomi di Kabupaten Tebo sebesar 6,78 persen. Pada tahun 2012 pertumbuhan ekonomi di Kabupaten Tebo mengalami penurunan menjadi 6,73 persen. Pada tahun 2013 pertumbuhan ekonomi menurun kembali menjadi 6,51 persen. Pada tahun 2014 pertumbuhan ekonomi di Kabupaten Tebo mengalami 
peningkatan menjadi sebesar 9,28 persen, dan pada tahun 2015 pertumbuhan ekonomi di Kabupaten Tebo sebesar 5,28 persen

Menurut Sukirno (2004), efek buruk dari pengangguran adalah mengurangi pendapatan masyarakat yang pada akhirnya mengurangi tingkat kemakmuran yang telah dicapai seseorang. Semakin turunnya kesejahteraan masyarakat karena menganggur tentunya akan meningkatkan peluang mereka terjebak dalam kemiskinan karena tidak memiliki pendapatan. Apabila pengangguran di suatu negara sangat buruk, kekacauan politik dan sosial selalu berlaku dan menimbulkan efek yang buruk bagi kesejahteraan masyarakat dan prospek pembangunan ekonomi dalam jangka panjang.

Berdasarkan Badan Pusat Statistik Tahun 2015 tingkat pengangguran terbuka di Kabupaten Tebo selama lima tahun terakhir mengalami fluktuasi. Pada Tahun 2011 pengangguran terbuka di Kabupaten Tebo sebesar 3,25 persen. Pada Tahun 2012 tingkat pengangguran terbuka di Kabupaten Tebo menurun menjadi 2,10 persen. Pada tahun 2013 tingkat pengangguran terbuka kembali menurun dari tahun sebelumnya menjadi sebanyak 0,73 persen. Pada Tahun 2014 tingkat pengangguran terbuka di Kabupaten Tebo meningkat dari tahun sebelumnya menjadi 3,86 persen. Pada tahun 2015 tingkat pengangguran terbuka di Kabupaten Tebo menurun dari tahun sebelumnya menjadi 1,25 persen.

Penduduk bekerja juga merupakan salah satu variabel penting untuk menanggulangi angka kemiskinan. Semakin besar jumlah proporsi penduduk bekerja maka diharapkan akan memberikan kontribusi nyata terhadap pemenuhan kebutuhan keluarga. Penduduk bekerja juga menjadi gambaran tentang keberhasilan pemerintah dalam mendorong permberdayaan masyarakat untuk membangkitkan potensi masyarakat. Semakin bertambah jumlah penduduk bekerja maka akan semakin besar kontribusinya terhadap pendapatan keluarga dan diharapkan akan semakin berkurang pula jumlah penduduk miskin

Selain dengan uraian di atas maka penelitian ini mencoba menganalisa pengaruh pertumbuhan ekonomi jumlah tenaga kerja dan pengangguran terhadap perkembangan jumlah penduduk miskin di kabupaten Tebo. Selanjutnya sejalan dengan hal tersebut adapun judul dari penelitian ini adalah; " Analisis Pengaruh Pertumbuhan Ekonomi dan Pengangguran Terbuka Terhadap Jumlah Penduduk Miskin di Kabupaten Tebo.

\section{METODE}

\section{Metode analisis deskriptif}

Metode yang digunakan dalam penelitian ini adalah metode analisis deskriptif. Analisis deskriptif merupakan analisis yang dilakukan berdasarkan perkembangan data yang dianalisis secara deskriptif untuk melihat perkembangan suatu wilayah. Untuk menjawab tujuan penelitian pertama maka digunakan analisis Pertumbuhan Ekonomi dengan rumus (Dajan, 1986) :

Dimana:

$$
P E=\frac{P D R B_{t-} P D R B_{t-1}}{P D R B_{t-1}} \quad x 100 \%
$$

$$
\begin{array}{ll}
\text { PE } & \text { : Pertumbuhan ekonomi (economic Growth) } \\
\text { PDRBt } & \text { : PDRB tahun } \mathrm{t} \\
\text { PDRBt-1 } & : \text { PDRB tahun sebelumnya }
\end{array}
$$

\section{Perkembangan pertumbuhan jumlah penduduk miskin}

Masalah kemiskinan memang telah lama ada sejak dahulu kala. Pada masa lalu umumnya masyarakat menjadi miskin karena kurang pangan, tetap miskin dalam bentuk minimnya kemudahan / materi, dari ukuran kehidupan modern pada masa kini mereka 
tidak menikmati fasilitas pendidikan, pelayanan kesehatan, dan kemudahan-kemudahan lainnya. Rumus untuk mencari perkembangan jumlah penduduk miskin sebagai berikut:

Dimana :

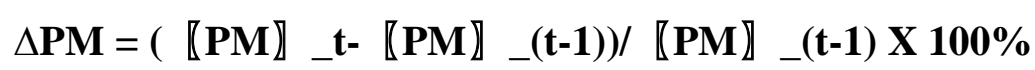

$\triangle \mathrm{PM}=$ Pertumbuhan jumlah penduduk miskin

PMt =Jumlah penduduk miskin tahun $\mathrm{t}$

PMt-1 =Jumlah penduduk miskin tahun sebelumnya

\section{Perkembangan pengangguran terbuka}

Pengangguran sering kali menjadi masalah dalam perekonomian diseluruh bagian wilayah Indonesia. Karena apabila jumlah ataupun tingkat pengangguran ini semakin meningkat dan terus meningkat maka pertumbuhan pertumbuhan ekonomi akan mengalami masalah. Rumus mencari perkembangan pengangguran terbuka sebagai berikut:

$$
\Delta \mathrm{PT}=(\mathbf{P T t}-\mathrm{PTt}-1) /(\mathbf{P T t}-1) \mathbf{X} 100 \%
$$

Dimana :

PT =perkembangan pengangguran terbuka

PTt =Pengangguran terbuka tahun $\mathrm{t}$

PTt-1 =Pengangguran terbuka tahun sebelumnya

\section{Perkembangan indeks kedalaman kemiskinan}

Indeks kedalaman kemiskinan (Poverty Gap Index-P1), merupakan ukuran ratarata kesenjangan pengeluaran masing-masing penduduk miskin terhadap garis kemiskinan. Semakin tinggi nilai indeks, semakin jauh nilai rata-rata pengeluaran penduduk dari garis kemiskinan. Rumus mencari perkembangan indeks kedalaman kemiskinan sebagai berikut:

\section{IKK = (IKKt-IKKt-1)/(IKKt-1)X 100\%}

Dimana :

IKK =perkembangan indeks kedalaman kemiskinan

IKKt $=$ Indeks kedalaman kemiskinan tahun $\mathrm{t}$

IKKt-1 =Indeks kedalaman kemiskinan tahun sebelumnya

\section{Perkembangan Indeks keparahan Kemiskinan}

Indeks keparahan kemiskinan (Poverty Severity Index-P2) memberikan gambaran mengenai penyebaran pengeluaran diantara penduduk miskin. Semakin tinggi nilai indeks, semakin tinggi ketimpangan pengeluaran diantara penduduk miskin. Rumus mencari perkembangan indeks keparahan kemiskinan sebagai berikut:

Dimana :

$$
\text { IKK }=(\text { IKKt-IKKt-1)/(IKKt-1)X } 100 \%
$$

IKK = Perkembangan indeks keparahan kemiskinan

IKKt $=$ Indeks keparahan kemiskinan tahun $\mathrm{t}$

IKKt-1 = Indeks keparahan kemiskinan tahun sebelumnya

Untuk melihat pengaruh pertumbuhan ekonomi dan Pengangguran terhadap jumlah penduduk miskin di Kabupaten Tebo, maka digunakan analisis regresi linier berganda, dengan menggunakan rumus sebagai berikut :

$$
\mathbf{P M}=\boldsymbol{\beta 0}+\boldsymbol{\beta 1 P E}+\boldsymbol{\beta 2 P T}+\mathrm{e}
$$




\section{Dimana :}

$\begin{array}{ll}\text { PM } & \text { : Jumlah Penduduk Miskin } \\ \beta 0 & \text { : Nilai konstanta } \\ \text { PE } & \text { : Pertumbuhan Ekonomi } \\ \text { PT } & \text { : Pengangguran Terbuka } \\ \beta 1 \beta 2 & \text { : Koefisien } \\ \text { e } & \text { : Standar error }\end{array}$

\section{Uji F (t-test)}

Uji ini pada dasarnya untuk menunjukkan apakah semua variabel bebas yang dimasukkan dalam model mempunyai pengaruh secara bersama-sama terhadap variabel terikat dengan cara: 1) Menentukan hipotesis yang akan diuji (Ho dan Ha); 2) Menentukan level of significance ( $\alpha$ ) tertentu; 3) Menentukan kriteria pengujian dengan membandingkan nilai F-tabel dan F-hitung, dan, 4) Menarik kesimpulan.

Dengan menggunkan keyakinan atau signifikansi 90\% ( $\alpha$ 10\%) maka F-hit lebih besar daripada F-tabel maka Ho ditolak, artinya variabel bebas secara bersama-sama mempengaruhi variabel tidak bebas. Nilai F-hit dicari dengan cara sebagai berikut:

$$
F-\text { hitung }=\frac{R^{2} /(k-1)}{\left(1-R^{2}\right) /(n-k)}
$$

Dimana:

$\mathrm{R}^{2} \quad=$ koefisien determinasi

$\mathrm{K} \quad=$ jumlah variabel bebas

$\mathrm{n} \quad=$ jumlah observas

Maka dengan derajat tertentu F- hitung < F- table, Maka Ho yang diterima artinya secara bersama-sama variabel independen secara signifikan tidak di pengaruhi variabel dependen. F- hitung > F- table, Maka Ho yang diterima artinya secara bersamasama variabel independen secara signifikan di pengaruhi variabel dependen

\section{Uji t (t-test)}

Uji ini dimaksudkan untuk melihat signifikasi koefisien regresi secara parsial/terpisah. Nilai t-hitung dapat dicari dengan formulasi sebagai berikut :

Dimana :

$$
\text { t-hitung }=\frac{\alpha_{1}}{\operatorname{SE} \alpha_{1}}
$$

$\alpha_{1} \quad$ : koefisien dari regresi Xi

$\mathrm{SE} \alpha_{1}$ : nilai standar error $\mathrm{Xi}$

Dalam uji t ini di gunakan keyakinan atau signifikansi $90 \%(\alpha 10 \%)$ hipotesis sebagai berikut, Ho : $\alpha_{1}-\alpha$ dan Ha $: \alpha_{1} * \alpha$. Dengan kriteria pengujian: jika t-hitung $>$ ttabel maka Ho di tolak. Artinya terdapat pengaruh yang signifikan antara variabel $\mathrm{X}$ terhadap variabel $\mathrm{Y}$, jika t-hitung < t-tabel maka Ho di terima, artinya tidak terdapat pengaruh yang signifikan antara variabel $\mathrm{X}$ terhadap variabel $\mathrm{Y}$.

\section{Koefisien determinasi $\left(\mathbf{R}^{\mathbf{2}}\right)$}

Koefisien determinasi ini mengukur seberapa jauh kemampuan model dalam menerangkan variasi variabel terikat. Koefisien ini nilainya antara nol (0) sampai dengan satu (1). Semakin besar nilai koefisien tersebut maka variabel-variabel bebas 
lebih mampu menjelaskan variasi variabel terikatnya. Untuk menghitung besarnya determinan $\left(\mathrm{R}^{2}\right)$ dapat digunakan rumus sebagai berikut (Gujarati, 2003):

Dimana:

$$
R^{2}=\frac{E S S}{T S S}=1-\frac{R^{2} /(k-1)}{\left(1-R^{2}\right) /(n-k)}
$$

$$
\begin{array}{ll}
\mathrm{R}^{2} & =\text { koefisien determinasi } \\
\mathrm{ESS} & =\text { Jumlah kuadrat residual } \\
\mathrm{TSS} & =\text { Total jumlah kuadrat residual } \\
\mathrm{n} & \text { =Jumlah observasi } \\
\mathrm{K} & \text { =Jumlah parameter (termasuk intersep) }
\end{array}
$$

\section{Uji normalitas}

Uji normalitas bertujuan untuk menguji apakah dalam model regresi variabel dependen dan independen keduanya mempunyai distribusi normal atau tidak. Uji normalitas data dalam penelitian ini menggunakan analisis grafik. Untuk memperjelas tentang sebaran data dalam penelitian ini maka akan disajikan dalam grafik normal Pplot. Dimana dasar pengambilan keputusan menurut Ghozali (2011) yaitu: Jika data menyebar jauh dari garis diagonal atau tidak mengikuti arah garis diagonal atau grafik histogram tidak menunjukkan pola distribusi normal, maka model regresi tidak memenuhi asumsi normalitas.

\section{Uji multikolinieritas}

Hubungan linier antara variabel independen dalam regresi berganda disebut multikolinieritas. Uji multikolinearitas bertujuan menguji apakah dalam regresi ditemukan adanya korelasi antar variabel bebas (independen). Model regresi yang baik seharusnya tidak mengandung korelasi di antara variabel-variabel independen. Pendeteksian keberadaan multikolinearitas dapat dilihat dari nilai tolerance dan lawannya Variance Inflation Factor (VIF). Kedua ukuran ini menunjukkan variabel independen manakah yang dijelaskan oleh variabel independen lainnya. Apabila nilai tolerance di atas 10 persen dan VIF di bawah 10, maka dapat disimpulkan bahwa model regresi bebas dari multikolinearitas (Ghozali, 2011).

\section{Uji autokorelasi}

Autokorelasi merupakan korelasi antar satu variabel gangguan dengan variabel gangguan yang lain. Adanya autokorelasi dalam model regresi akan mengakibatkan model regresi tersebut memiliki karakteristik sebagai berikut (Ghozali, 2011).

1. Estimator atau model masih linier.

2. Estimator atau model masih tidak bias.

3. Meskipun demikian, estimator atau model tidak lagi memiliki varian yang minimum (no longer best)

\section{HASIL DAN PEMBAHASAN}

Pada bagian ini akan dipresentasikan pengaruh pertumbuhan ekonomi dan pengangguran terbuka terhadap jumlah penduduk miskin di Kabuapaten Tebo Tahun 2002-2015. Dengan menggunakan persamaan regresi berganda dan menggunakan program spss 19. Sebagai variabel independen (bebas) adalah pertumbuhan ekonomi dan pengangguran terbuka sedangkan variabel dependent adalah jumlah penduduk miskin. Dari persamaan regresi linear berganda diperoleh hasil estimasi sebagai berikut 
Tabel 1. Persamaan model regresi linear berganda

\begin{tabular}{|c|c|c|c|c|c|}
\hline \multirow{2}{*}{ Unstandardized } & \multicolumn{2}{|c|}{ Standardized Modal } & \multicolumn{3}{|c|}{ Coefficients } \\
\hline & B & Std. Error & Beta & $\mathbf{T}$ & Sig \\
\hline Constant & 4,226 & 0,077 & & 54,846 & 0,000 \\
\hline $\begin{array}{l}\text { Pertumbuhan } \\
\text { Ekonomi }\end{array}$ & 0,022 & 0,010 & 0,542 & 2,213 & 0,043 \\
\hline $\begin{array}{l}\text { Pengangguran } \\
\text { terbuka }\end{array}$ & $-0,021$ & 0,010 & $-0,516$ & $-2,105$ & 0,053 \\
\hline
\end{tabular}

Sumber: Data diolah, 2016

Dari hasil koefesien regresi maka model regresi dapat disederhanakan sebagai berikut:

$$
\begin{aligned}
& \mathrm{PM}=4,226+0,022 \mathrm{PE}-0,21 \mathrm{PT} \\
& \mathrm{t} \text {-hitung }=(54,846)(2,213)(-2,105) \\
& \text { F-hitung }=4,31 \\
& \mathrm{R}^{2}=0,580
\end{aligned}
$$

Dari hasil hasil regresi diperoleh nilai konstanta 4,226 artinya apabila seluruh variabel independen yaitu pertumbuhan ekonomi dan pengangguran terbuka konstanta atau tetap maka jumlah penduduk miskin akan bertambah 422,6 orang/jiwa. Sementara $\mathrm{R}^{2}$ sebeasar 0,580 berarti 58,0 persen variabel dependen mampu dijelaskan oleh model yang digunakan, sedangkan sisanya 42,0 persen dijelaskan oleh variabel lain diluar estimasi model.

\section{Uji koefesien determinasi}

Nilai $\mathrm{R}^{2}$ menunjukan seberapa besar proporsi variabel bebas berpengaruh terhadap variabel terikat. Hasil regresi dapat dilihat dari nilai $\mathrm{R}^{2}$ sebesar 0,580 artinya 58,0 persen jumlah penduduk miskin di Kabuaten Tebo dipengaruhi oleh pertumbuhan ekonomi dan pengangguran terbuka sedangkan sisanya sebesar 42,0 persen diperngaruhi oleh variabel lain yang tidak termasuk dalam penelitian ini.

\section{Uji F statistic (secara bersama-sama)}

Hasil regresi menunjukan nilah $\mathrm{F}$ hitung sebesar 4,831 dengan tingkat kepercayaan $90 \%$, diperoleh nilai $\mathrm{F}$ tabel sebesar 3,74 hasil regresi menunjukan Fhitung $>\mathrm{F}$ tabel maka (Ho) ditolak dan (Ha) diterima artinya secara bersama-sama pertumbuhan ekonomi dan pengangguran terbuka berpengaruh signifikan terhadap jumlah penduduk miskin di Kabupaten Tebo.

\section{Uji t (uji parsial)}

Untuk mengetahui variabel bebas pengaruhya terhadap variabel terikat, uji t dilakukan dengan membandingkan nilai uji t hitung dengan $\mathrm{t}$ tabel. Hasil regresi menunjukan nilai t hitung untuk variabel pertumbuhan ekonomi adalah sebesar 2,213 dengan tingkat kepercayaan 90\% diperoleh $\mathrm{t}$ tabel sebesar 1,761 hasil regresi menunjukan $\mathrm{t}$ hitung $>\mathrm{t}$ tabel maka dalam kasus ini (Ho) ditolak dan (Ha) diterima yang artinya pertumbuhan ekonomi memiliki pengaruh signifikan terhadap jumlah penduduk miskin di Kabupaten Tebo.. Hasil regresi menunjukan nilai t hitung untuk variabel pengangguran terbuka adalah sebesar -2,105 dengan tingkat kepercayaan 90\% diperoleh 
$\mathrm{t}$ tabel sebesar 1,761 hasil regresi menunjukan $\mathrm{t}$ hitung $>\mathrm{t}$ tabel maka dalam kasus ini (Ho) ditolak dan (Ha) diterima yang artinya pengangguran terbuka memiliki pengaruh negatif dan signifikan terhadap jumlah penduduk miskin di Kabupaten Tebo.

\section{KESIMPULAN DAN SARAN}

\section{Kesimpulan}

Dari hasil dan pembahasan yang telah dikemukakan pada bab sebelumnya maka dapat diambil kesimpulan sebagai yaitu, rata-rata pertumbuhan ekonomi di Kabupaten tebo periode tahun 2002-2015 adalah sebesar 5,89 persen pertahun. Rata-rata pengangguran terbuka mengalami perkembangan di periode tahun 2002-2015 adalah sebesar 25,45 persen pertahun. Rata-rata jumlah penduduk miskin di Kabupaten Tebo mengalami penurunan pada periode tahun 2002-2015 adalah sebesar 1,36 persen.

Berdasarkan uji $\mathrm{F}$ variabel pertumbuhan ekonomi dan pengangguran terbuka terhadap jumlah penduduk miskin. Variabel pertumbuhan ekonomi adalah sebesar 2,213 dengan tingkat kepercayaan 90\% diperoleh $t$ tabel sebesar 1,761 hasil regresi menunjukan $\mathrm{t}$ hitung $>\mathrm{t}$ tabel artinya pertumbuhan ekonomi memiliki pengaruh negatif terhadap jumlah penduduk miskin di Kabupaten Tebo. Variabel pengangguran terbuka adalah sebesar 2,126 dengan tingkat kepercayaan 90\% diperoleh $\mathrm{t}$ tabel sebesar 1,761 hasil regresi menunjukan $\mathrm{t}$ hitung $>\mathrm{t}$ tabel yang artinya pengangguran terbuka memiliki pengaruh negatif terhadap jumlah penduduk miskin di Kabupaten Tebo.

\section{Saran}

Dari hasil penelitian walaupun pertumbuhan ekonomi berpengaruh merunkan jumlah penduduk miskin di Kabupaten Tebo dengan demikian pemerintah daerah haruslah mempertimbangkan tentang memberdayaan dalam memajukan pertumbuhan ekonomi Kabupaten Tebo, dengan cara pemberdayaan perubahan sektor ekonomi yang berpotensial. Dilihat dari hasil regresi terlihat pengangguran terbuka berpengaruh menambah jumlah penduduk miskin dengan hasil tersebut diharapkan pemerintah daerah agar dapat memprioritaskan penciptaan lapangan pekerjaan pada sektor-sektor ekonomi yang padat tenaga kerja agar pengangguran menurun dan jumlah penduduk miskin akan berkurang

\section{DAFTAR PUSTAKA}

Arsyad, Lincolin, (1997). Ekonomi pembangunan. Edisi Kedua, STIE YKPN: Yogyakarta.

Ayu, (2009). Analisis tingkat jumlah penduduk miskin di Kota Jambi Periode 19942007. Skripsi Universitas Jambi: Jambi

Dajan, Anto, (1986). Pengantar metode statistik jilid I. LP3ES: Jakarta

Gujarati, Damodar, (2003). Economectric. Erlangga. Jakarta.

Hermansyah. 2009. Dampak pertumbuhan ekonomi terhadap kemiskinan penduduk di Kabupaten Sarolangun. Jurnal Universitas Jambi: Jambi 3(1), 12-13

Lesta (2013). Faktor-faktor yang mempengaruhi tingkat kemiskinan di Jawa Teangah. Jurnal Universitas Negeri Semarang : Semarang 2(1), 22-30

P Putriani, J Junaidi, JK Edi. (2019).Pengaruh pertumbuhan ekonomi, pendidikan dan kesehatan terhadap tingkat kemiskinan di Kota Jambi Periode 2004-2017, eJurnal Ekonomi Sumberdaya dan Lingkungan, 7 (3), 132-143

Paratdiredja, Ace.(2004). Ekonomika. UI Press: Jakarta.

Prabowo, (2014). Anlisis pengaruh pertumbuhan ekonomi, upah minimum, dan tingkat pengangguran terhadap jumlah penduuduk miskin di Kabupaten Brebes Tahun 1997-2012. Skripsi Universitas Diponegoro Semarang: Semarang 